\title{
PERSEPSI MAHASISWA TERHADAP E-MODUL PEMBELAJARAN MATA KULIAH FISIKA ATOM DAN INTI
}

\author{
Haerul Pathoni ${ }^{1)}$, Jufrida ${ }^{2)}$, Ika Saputri ${ }^{3)}$, Wulan Sari ${ }^{4)}$ \\ 1),2) Dosen Pendidikan Fisika FKIP Universitas Jambi \\ 3),4) Mahasiswa Pendidikan Fisika FKIP Universitas Jambi \\ haerul.pathoni@gmail.com
}

\begin{abstract}
Based on observations in atomic physics and nuclear learning, there are some problems see during two semester of the course such as less using of instructional materials and instructional media in the process of learning. In addition, content of book used are books published in the 1990s years and never have been updated. The quantity of books of atomic physics and nuclear in the library is still very little. Therefore developed electronic modul (E-modul). This research used descriptif research. E-module is made using $3 D$ software pageflip professional. E-Module has been validated by experts for media and content of e-module. The result was perception of students on average $83.5 \%$ on core structure module and $89 \%$ on radioactivity module with very good category.
\end{abstract}

Keywords: E-module, Atomic physic and nuclear, 3D Pageflip Professional

\section{PENDAHULUAN}

Fisika atom dan inti merupakan salah satu mata kuliah yang dipelajari di prodi pendidikan fisika dengan bobot 3 SKS dan 3x50 tatap muka. Mata kuliah fisika atom dan inti memegang peran penting pada tingkat pembelajaran fisika di perguruan tinggi khususnya pada prodi pendidikan fisika. Fisika atom dan inti memuat materi mata kuliah fisika lanjut yang beririsan dengan mata kuliah fisika kuantum, fisika zat padat, dan fisika modern. Selain itu, mata kuliah ini juga kelanjutan dari mata kuliah dasar-dasar fisika yakni fisika dasar I dan fisika dasar II.

Berdasarkan hasil observasi dari proses pembelajaran yang dilakukan selama 2 semester dan analisis kebutuhan, didapatkan informasi adanya beberapa pokok permasalahan dalam perkuliahan mata kuliah fisika atom dan inti. Salah satu permasalahan yang dihadapi adalah permasalahan berupa bahan ajar dan media pembelajaran yang akan digunakan dalam proses perkuliahan. Bahan ajar yang digunakan adalah buku-buku yang sudah sangat lama dan perlu diperbahaui. Padahal jika menggunakan bahan ajar maka diharapkan dapat meningkatkan hasil belajar mahasiswa. Hasil penelitian (harijanto, 2007) menunjukkan penggunaan produk bahan ajar menunjukkan peningkatan hasil belajar mahasiswa, yang ditunjukkan oleh perbedaan mean skor pretest dan post-test 2.65. Selain itu penggunaan produk bahan ajar hasil pengembangan mampu meningkatkan skor mahasiswa sebesar $26.50 \%$.
Selain itu, bahan ajar yang digunakan pada perkuliahan fisika atom dan inti juga banyak dari berbagai sumber dan penerbit yang berbedabeda sehingga kadang terdapat konsep yang berbeda antara satu buku sumber dengan buku sumber yang lain. Selain itu, dari silabus perkuliahan juga terlihat bahwa kompetensikompetensi materi yang ingin dicapai pada proses perkuliahan juga terdapat dalam banyak buku sumber baik yang terdapat di perpustakaan atau yang dikoleksi dosen pengampu mata kuliah. Selain itu, jika dilihat dari kuantitasnya buku sumber yang membahas tentang materi fisika atom dan inti di perpustakaan juga masih sangat sedikit. Apabila hal ini dibiarkan terus menerus, maka akan berdampak buruk pada rendahnya kualitas belajar dan hasil belajar mahasiswa pada mata kuliah Fisika atom dan inti. Selain itu, penggunaan video, gambar, maupun media pembelajaran lainnya dalam perkuliahan jarang digunakan.

Perkembangan teknologi informasi dan komunikasi (TIK) yang cepat menuntut dosen bisa mengikutinya dengan cepat juga. Perkembangan TIK khsususnya pada teknologi pendidikan sudah sangat cepat. Pembelajaran dengan berbasis computer dengan bantuan software sudah sangat banyak. Salah satu software yang bisa digunakan adalah $3 D$ Fageflip Profesional. Software ini bisa digunakan untuk mengatasi permasalahan untuk mengembangkan inovasi pembelajaran dalam pembuatan bahan ajar berupa e-modul 
pada mata kuliah fisika atom dan inti. E-modul yang dikembangkan diharapkan sesuai dengan kompetensi-kompetensi yang diharapkan dari kurikulum program studi pendidikan fisika. Hal ini penting untuk mencapai target-target perkuliahan sehingga kualitas belajar mahasiswa dapat ditingkakan.

Pada Penelitian ini, masalah yang diteliti adalah bagaimana mendesign sebuah modul elektronik mata kuliah fisika atom dan inti dengan software 3D Fageflip professional untuk mempermudah perkuliahan mata kuliah tersebut. Sedangkan tuujuan penelitian ini adalah untuk mengetahui persepsi mahasiswa mengenai desain e-modul pembelajaran pada mata kuliah Fisika Atom dan Inti

\section{METODE PENELITIAN}

Penelitian ini adalah penelitian deskriftif kuantitatif untuk melihat persepsi mahasiswa terhadap e-modul pembelajaran yang sudah didesign dan dibuat oleh peneliti.

Untuk analisis data dilkukan uji validitas dengan product moment dan uji realibiltas dengan rumus alpha untuk instrumen penelitian. Selain itu, dilakukan juga validasi oleh ahli media dan ahli materi untuk mengetahui kesesuaian materi dengan Standar Kompetensi dan Kompetensi Dasar, keakuratan materi dan isi, pendukung materi pembelajaran, kemutakhiran materi, desain sampul modul, tampilan gambar, dan tampilan video dan animasi. Selanjutnya dilakukan pengambilan data persepsi mahasiswa. Teknik pengambilan data persepsi mahasiswa yaitu mengkuantutatifkan hasil checklist dengan member skor sesuai dengan bobot yang telah ditentukan sebelumnya, membuat tabulasi data, menghitung presentasi dari tiap-tiap sub variabel. dengan menggunakan persamaan

$$
\mathrm{P}=\frac{n}{N} \times 100 \%
$$

Keterangan:

$$
\begin{aligned}
& \mathrm{P}=\text { Persentase sub variabel } \\
& n \quad=\text { jumlah nilai tiap sub variabel } \\
& N \quad \text { Jumlah skor maksimum }
\end{aligned}
$$

Dari persentase yang telah diperoleh ditransformasikan ke dalam kalimat yang bersifat kualitatif dengan kriteria sebagai berikut
Tabel .1. Range Persentase dan Kriteria Kualitatif

\begin{tabular}{|c|c|c|}
\hline No. & Interval Persentase & Kriteria \\
\hline 1. & $84 \% \leq$ skor $\leq 100 \%$ & Sangat Baik \\
\hline 2. & $68 \% \leq$ skor $\leq 83 \%$ & Baik \\
\hline 3. & $52 \% \leq$ skor $\leq 67 \%$ & Cukup Baik \\
\hline 4. & $36 \% \leq$ skor $\leq 51 \%$ & Kurang Baik \\
\hline 5. & $20 \% \leq$ skor $\leq 35 \%$ & Tidak Baik \\
\hline \multicolumn{2}{|c}{ (Muhidin, 2009) }
\end{tabular}

Kevalidan suatu instrumen diketahui bila instrumen tersebut mampu mengukur apa yang diinginkan, dan dapat mengungkapkan fakta dari variabel yang diteliti secara tepat. Tinggi rendahnya validasi instrumen menunjukkan sejauh mana data terkumpul tidak menyimpang dari gambaran validasi yang dimaksud (Arikunto, 2010).

Untuk analisis validasi digunakan rumus korelasi product moment. Namun, pada pengolahan data digunakan software SPSS.21 untuk nilai korelasi (r) dengan kriteria sebagai berikut

$$
\begin{aligned}
& 0,800-1,000: \text { Sangat Tinggi } \\
& 0,600-0,799: \text { Tinggi } \\
& 0,400-0,599: \text { Cukup Tinggi } \\
& 0,200-0,399: \text { Rendah } \\
& 0,000 \text { - 0,199: Sangat Rendah }
\end{aligned}
$$

Begitu juga dengan analisis reabilitas juga dilakukan pada angket dari hasil uji coba. Reabilitas angket menggunakan rumus alpha . Namun, pada pengolahan data digunakan software SPSS.21 dengan kriteria sebagai berikut

$0,00 \leq \mathrm{r}_{\mathrm{xy}} \leq 0,20$ : reabilitas sangat rendah

$0,21 \leq \mathrm{r}_{\mathrm{xy}} \leq 0,40:$ reabilitas rendah

$0,41 \leq \mathrm{r}_{\mathrm{xy}} \leq 0,60$ : reabilitas sedang

$0,61 \leq \mathrm{r}_{\mathrm{xy}} \leq 0,80:$ reabilitas tinggi

$0,81 \leq \mathrm{r}_{\mathrm{xy}} \leq 1,00$ :reabilitas sangat tinggi.

\section{HASIL DAN PEMBAHASAN}

Design e-modul mata kuliah fisika atom inti pada materi radioaktivitas, struktur inti dengan menggunakan software 3D fageflip professional dapat dilihat pada gambar 1 . 


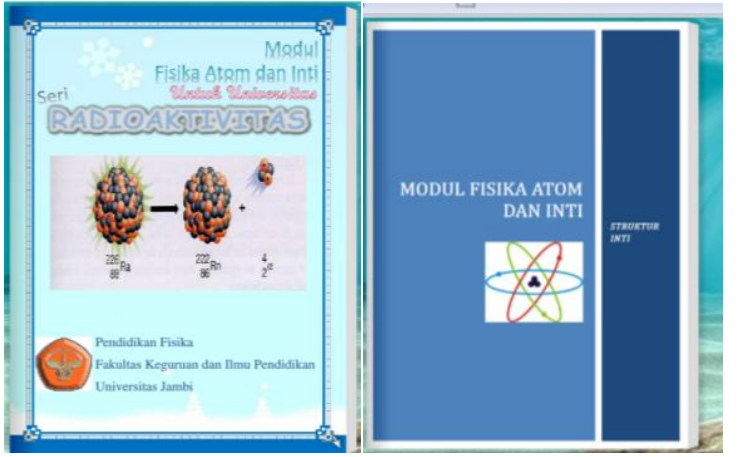

Gambar 1. Contoh design cover e-modul materi radioaktivitas dan materi struktur inti

Setelah e-modul selesai didesain maka emodul divalidasi oleh ahli media dan ahli materi. Hasil validasi oleh ahli media dan ahli materi mengenai media dan isi modul menunjukkan bahwa ada revisi pada modul mengenai video dan animasi yang terkini pada e-modul yang belum lengkap. Video yang diminta adalah video terkini tentang materi radioaktivitas dan struktur inti. Selain itu, validasi juga dilakukan untuk mengetahui kejelasan teks, kejelasan gambar, kemenarikan gambar, kesesuaian gambar dengan materi, kejelasan animasi, kemenarikan animasi, kesesuaian animasi dengan materi, kejelasan video, kemenarikan video, kesesuaian video dengan materi, penyajian materi, kejelasan kalimat, kejelasan istilah, kesesuaian contoh dengan materi, kemudahan belajar, ketertarikan menggunakan modul, dan peningkatan motivasi belajar.

Hasil validasi oleh ahli materi dan ahli media dapat dilihat seperti tabel 2 dan tabel 3 . Ahli media dan ahli materi adalah dosen pada pendidikan fisika Fakultas Keguruan dan Ilmu Pendidikan Universitas Jambi.

Tabel.2 Hasil Validasi ahli materi pada e-modul

\begin{tabular}{|c|c|c|c|c|c|}
\hline \multirow[t]{2}{*}{ No } & \multirow{2}{*}{$\begin{array}{l}\text { Indikator } \\
\text { Penilaian }\end{array}$} & \multirow[t]{2}{*}{ Pernyataan } & \multicolumn{2}{|c|}{ Penilaian } & \multirow[t]{2}{*}{ Saran } \\
\hline & & & Ya & Tidak & \\
\hline \multirow[t]{3}{*}{1.} & \multirow{3}{*}{$\begin{array}{l}\text { Kesesuaian } \\
\text { materi } \\
\text { dengan SK } \\
\text { dan KD }\end{array}$} & $\begin{array}{l}\text { 1. } \begin{array}{l}\text { Kelengkapan materi sesuai } \\
\text { dengan SK dan KD }\end{array}\end{array}$ & $\sqrt{ }$ & & \\
\hline & & $\begin{array}{l}\text { 2. Keleluasaan materi sesuai } \\
\text { dengan SK dan KD }\end{array}$ & $\sqrt{ }$ & & \\
\hline & & $\begin{array}{l}\text { 3. Kedalaman materi sesuai } \\
\text { dengan SK dan KD }\end{array}$ & $\sqrt{ }$ & & \\
\hline \multirow[t]{6}{*}{2.} & $\begin{array}{l}\text { Keakuratan } \\
\text { materi dan } \\
\text { isi }\end{array}$ & $\begin{array}{l}\text { 4. Konsep dan definisi yang } \\
\text { dijelaskan akurat }\end{array}$ & $\sqrt{ }$ & & \\
\hline & & $\begin{array}{l}\text { 5. Penjelasan prinsip-prinsip } \\
\text { materi akurat }\end{array}$ & $\sqrt{ }$ & & \\
\hline & & $\begin{array}{ll}\text { 6. } & \text { Contoh soal yang } \\
\text { digunakan akurat }\end{array}$ & $\sqrt{ }$ & & \\
\hline & & $\begin{array}{l}\text { 7. Gambar, diagram, dan } \\
\text { ilustrasi yang ditampilkan } \\
\text { akurat }\end{array}$ & $\sqrt{ }$ & & \\
\hline & & $\begin{array}{ll}\text { 8. } & \text { Keluasan materi yang } \\
\text { disampaikan melalui 3D } \\
\text { Pageflip Professional }\end{array}$ & $\sqrt{ }$ & & \\
\hline & & $\begin{array}{l}\text { 9. Keluasan materi yang } \\
\text { disampaikan }\end{array}$ & $\sqrt{ }$ & & \\
\hline \multirow[t]{3}{*}{3.} & \multirow{3}{*}{$\begin{array}{l}\text { Pendukung } \\
\text { materi } \\
\text { pembelajara } \\
\text { n }\end{array}$} & $\begin{array}{l}\text { 10. Terdapat unsur penalaran } \\
\text { dalam materi yang } \\
\text { disampaikan }\end{array}$ & $\sqrt{ }$ & & \\
\hline & & $\begin{array}{l}\text { 11. Ada keterkaitan yang tepat } \\
\text { antar materi }\end{array}$ & $\sqrt{ }$ & & \\
\hline & & 12. Bahasa yang digunakan & $\sqrt{ }$ & & \\
\hline
\end{tabular}




\begin{tabular}{|c|c|c|c|c|c|}
\hline \multirow[t]{6}{*}{ No } & \multirow{6}{*}{$\begin{array}{l}\text { Indikator } \\
\text { Penilaian }\end{array}$} & \multirow[t]{2}{*}{ Pernyataan } & \multicolumn{2}{|c|}{ Penilaian } & \multirow[t]{2}{*}{ Saran } \\
\hline & & & Ya & Tidak & \\
\hline & & \multicolumn{4}{|l|}{$\begin{array}{l}\text { mampu berkomunikasi } \\
\text { dengan pembaca }\end{array}$} \\
\hline & & $\begin{array}{l}\text { 13. Ada unsur penerapan yang } \\
\text { diberikan dalam } \\
\text { penyampaian materinya }\end{array}$ & $\sqrt{ }$ & & \\
\hline & & $\begin{array}{l}\text { 14. Mampu menyampaikan } \\
\text { materi dengan menarik }\end{array}$ & $\sqrt{ }$ & & \\
\hline & & $\begin{array}{l}\text { 15. Mendorong untuk mencari } \\
\text { informasi lebih lanjut }\end{array}$ & $\sqrt{ }$ & & \\
\hline \multirow[t]{5}{*}{4.} & $\begin{array}{l}\text { Kemutakhir } \\
\text { an materi }\end{array}$ & $\begin{array}{l}\text { 16. Materi yang disampaikan } \\
\text { sesuai dengan } \\
\text { perkembangan ilmu } \\
\text { pengetahuan }\end{array}$ & $\sqrt{ }$ & & \\
\hline & & $\begin{array}{l}\text { 17. Gambar diagram dan } \\
\text { ilustrasi aktual }\end{array}$ & $\sqrt{ }$ & & \\
\hline & & 18. Animasi dan video aktual & & $\sqrt{ }$ & $\begin{array}{l}\text { Tambahka } \\
\mathrm{n} \quad \text { video } \\
\text { dan } \\
\text { animasi } \\
\text { yang } \\
\text { terupdate } \\
\text { pada } \\
\text { modul }\end{array}$ \\
\hline & & $\begin{array}{l}\text { 19. Contoh kasus yang } \\
\text { digunakan beragam }\end{array}$ & $\sqrt{ }$ & & \\
\hline & & $\begin{array}{l}\text { 20. Acuan pustaka yang } \\
\text { digunakan mutakhir }\end{array}$ & $\sqrt{ }$ & & \\
\hline
\end{tabular}

Tabel 3. Hasil validasi ahli media pada e-modul

\begin{tabular}{|c|c|c|c|c|}
\hline \multirow[t]{2}{*}{ No } & \multirow{2}{*}{$\begin{array}{l}\text { Indikator } \\
\text { Penilaian }\end{array}$} & \multirow[t]{2}{*}{ Pernyataan } & Penilaian & \multirow[t]{2}{*}{ Saran } \\
\hline & & & $\begin{array}{ll}\text { Ya } & \text { Tidak } \\
\end{array}$ & \\
\hline \multirow[t]{6}{*}{1} & \multirow[t]{6}{*}{$\begin{array}{l}\text { Desain sampul } \\
\text { modul }\end{array}$} & $\begin{array}{l}\text { 1. Penulisan judul modul } \\
\text { sudah cocok }\end{array}$ & $\sqrt{ }$ & \\
\hline & & $\begin{array}{l}\text { 2. Ukuran huruf pada } \\
\text { tulisan sudah cocok }\end{array}$ & $\sqrt{ }$ & \\
\hline & & $\begin{array}{l}\text { 3. Warna tulisan sudah } \\
\text { sesuai }\end{array}$ & $\sqrt{ }$ & \\
\hline & & $\begin{array}{l}\text { 4. Penggunaan kata sudah } \\
\text { sesuai }\end{array}$ & $\sqrt{1}$ & \\
\hline & & $\begin{array}{l}\text { 5. Tulisan yang digunakan } \\
\text { jelas }\end{array}$ & $\sqrt{ }$ & \\
\hline & & $\begin{array}{l}\text { Kombinasi warna tulisan } \\
\text { dengan background sudah } \\
\text { cocok }\end{array}$ & $\sqrt{ }$ & \\
\hline \multirow[t]{4}{*}{2.} & \multirow{4}{*}{$\begin{array}{l}\text { Tampilan } \\
\text { Gambar }\end{array}$} & 7. Warna sudah cocok & $\sqrt{ }$ & \\
\hline & & 8. Ukuran gambar sudah pas & $\sqrt{ }$ & \\
\hline & & $\begin{array}{l}\text { 9. Kesesuaian gambar } \\
\text { dengan background }\end{array}$ & $\sqrt{ }$ & \\
\hline & & 10. Variasi gambar & $\sqrt{ }$ & \\
\hline 3. & Tampilan & 11. Warna sudah cocok & $\sqrt{ }$ & \\
\hline
\end{tabular}




\begin{tabular}{|c|c|c|c|c|c|}
\hline \multirow[t]{5}{*}{ No } & \multirow{5}{*}{$\begin{array}{l}\text { Indikator } \\
\text { Penilaian } \\
\text { dan animasi }\end{array}$} & \multirow[t]{2}{*}{ Pernyataan } & \multicolumn{2}{|c|}{ Penilaian } & \multirow[t]{3}{*}{ Saran } \\
\hline & & & $\mathrm{Ya}$ & \multirow[t]{2}{*}{ Tidak } & \\
\hline & & $\begin{array}{l}\text { 12. Ukuran video dan } \\
\text { animasi sudah pas }\end{array}$ & $\sqrt{ }$ & & \\
\hline & & $\begin{array}{lr}\text { 13. Kesesuaian } & \text { video dan } \\
\text { animasi } & \text { dengan } \\
\text { background } & \end{array}$ & $\sqrt{ }$ & & \\
\hline & & 14. Variasi video dan animasi & & $\sqrt{ }$ & $\begin{array}{l}\text { Tambahkan } \\
\text { lebih banyak } \\
\text { Variasi Video } \\
\text { dan animasi } \\
\text { pada e-modul }\end{array}$ \\
\hline 4. & Desain & $\begin{array}{l}\text { 15. Konsistensi, format, } \\
\text { organisasi dan daya tarik } \\
\text { modul menarik }\end{array}$ & $\sqrt{ }$ & & \\
\hline
\end{tabular}

Setelah dilakukan validasi oleh ahli maka langkah selanjutnya adalah uji coba kelompok kecil dan uji coba kelompok besar untuk pengambilan data persepsi mahasiswa.
Data persepsi mahasiswa terhadap E-modul dapat dilihat pada tabel 4.

.Tabel 4. Data Persepsi Mahasiswa terhadap E-modul

\begin{tabular}{|c|c|c|c|c|c|}
\hline $\begin{array}{l}\text { Indikator } \\
\text { penilaian }\end{array}$ & Pernyataan & $\begin{array}{l}\text { e-modul } \\
\text { i }(\%)\end{array}$ & $\begin{array}{l}\text { e-modul } \\
\text { ii }(\%)\end{array}$ & $\begin{array}{l}\text { Kritera e- } \\
\text { modul i }\end{array}$ & $\begin{array}{l}\text { Kritera e- } \\
\text { modul ii }\end{array}$ \\
\hline Kejelasan teks & $\begin{array}{l}\text { Teks atau tulisan } \\
\text { pada modul ini } \\
\text { mudah dibaca }\end{array}$ & 81 & 89 & Baik & $\begin{array}{l}\text { Sangat } \\
\text { Baik }\end{array}$ \\
\hline \multirow[t]{2}{*}{$\begin{array}{l}\text { Kejelasan } \\
\text { gambar }\end{array}$} & $\begin{array}{l}\text { Ukuran gambar } \\
\text { yang disajikan } \\
\text { sudah sesuai (tidak } \\
\text { terlalu besar dan } \\
\text { tidak terlalu kecil) }\end{array}$ & 87 & 87 & $\begin{array}{l}\text { Sangat } \\
\text { baik }\end{array}$ & $\begin{array}{l}\text { Sangat } \\
\text { Baik }\end{array}$ \\
\hline & $\begin{array}{l}\text { Warna dan bentuk } \\
\text { gambar yang } \\
\text { ditampilkan jelas }\end{array}$ & 93 & 86 & $\begin{array}{l}\text { Sangat } \\
\text { baik }\end{array}$ & $\begin{array}{l}\text { Sangat } \\
\text { Baik }\end{array}$ \\
\hline $\begin{array}{l}\text { Kemenarikan } \\
\text { gambar }\end{array}$ & $\begin{array}{l}\text { Gambar yang } \\
\text { disajikan menarik }\end{array}$ & 90 & 91 & $\begin{array}{l}\text { Sangat } \\
\text { baik }\end{array}$ & $\begin{array}{l}\text { Sangat } \\
\text { Baik }\end{array}$ \\
\hline $\begin{array}{l}\text { Kesesuaian } \\
\text { gambar dengan } \\
\text { materi }\end{array}$ & $\begin{array}{l}\text { Gambar yang } \\
\text { disajikan sesuai } \\
\text { dengan materi }\end{array}$ & 85 & 87 & $\begin{array}{l}\text { Sangat } \\
\text { baik }\end{array}$ & $\begin{array}{l}\text { Sangat } \\
\text { Baik }\end{array}$ \\
\hline $\begin{array}{l}\text { Kejelasan } \\
\text { animasi }\end{array}$ & $\begin{array}{l}\text { Animasi yang } \\
\text { disajikan sudah } \\
\text { sesuai (tidak terlalu } \\
\text { besar dan tidak } \\
\text { terlalu kecil) }\end{array}$ & 85 & 91 & $\begin{array}{l}\text { Sangat } \\
\text { baik }\end{array}$ & $\begin{array}{l}\text { Sangat } \\
\text { Baik }\end{array}$ \\
\hline $\begin{array}{l}\text { Kemenarikan } \\
\text { animasi }\end{array}$ & $\begin{array}{l}\text { Animasi yang } \\
\text { disajikan menarik }\end{array}$ & 85 & 88 & $\begin{array}{l}\text { Sangat } \\
\text { baik }\end{array}$ & $\begin{array}{l}\text { Sangat } \\
\text { Baik }\end{array}$ \\
\hline $\begin{array}{l}\text { Kesesuaian } \\
\text { animasi dengan } \\
\text { materi }\end{array}$ & $\begin{array}{l}\text { Animasi yang } \\
\text { disajikan sesuai } \\
\text { dengan materi }\end{array}$ & 85 & 88 & $\begin{array}{l}\text { Sangat } \\
\text { baik }\end{array}$ & $\begin{array}{l}\text { Sangat } \\
\text { Baik }\end{array}$ \\
\hline Kejelasan video & $\begin{array}{l}\text { Video yang } \\
\text { disajikan sudah } \\
\text { sesuai (tidak terlalu }\end{array}$ & 85 & 85 & $\begin{array}{l}\text { Sangat } \\
\text { baik }\end{array}$ & $\begin{array}{l}\text { Sangat } \\
\text { Baik }\end{array}$ \\
\hline
\end{tabular}




\begin{tabular}{|c|c|c|c|c|c|}
\hline & $\begin{array}{l}\text { besar dan tidak } \\
\text { terlalu kecil) }\end{array}$ & & & & \\
\hline $\begin{array}{l}\text { Kemenarikan } \\
\text { video }\end{array}$ & $\begin{array}{l}\text { Video yang } \\
\text { disajikan menarik }\end{array}$ & 87 & 88 & $\begin{array}{l}\text { Sangat } \\
\text { baik }\end{array}$ & $\begin{array}{l}\text { Sangat } \\
\text { Baik }\end{array}$ \\
\hline $\begin{array}{l}\text { Kesesuaian } \\
\text { video dengan } \\
\text { materi }\end{array}$ & $\begin{array}{l}\text { Video yang } \\
\text { disajikan sesuai } \\
\text { dengan materi }\end{array}$ & 81 & 84 & Baik & $\begin{array}{l}\text { Sangat } \\
\text { Baik }\end{array}$ \\
\hline \multicolumn{6}{|c|}{ Penyajian Materi dalam Modul } \\
\hline \multirow[t]{3}{*}{$\begin{array}{l}\text { Penyajian } \\
\text { materi }\end{array}$} & $\begin{array}{l}\text { Penyajian materi } \\
\text { dimulai dari yang } \\
\text { sederhana ke yang } \\
\text { kompleksd }\end{array}$ & 82 & 81 & Baik & Baik \\
\hline & $\begin{array}{l}\text { Penyajian materi } \\
\text { dalam modul } \\
\text { sederhana dan } \\
\text { mudah dipahami }\end{array}$ & 77 & 77 & Baik & Baik \\
\hline & $\begin{array}{l}\text { Urutan penyajian } \\
\text { materi jelas }\end{array}$ & 73 & 83 & Baik & $\begin{array}{l}\text { Sangat } \\
\text { Baik }\end{array}$ \\
\hline \multirow[t]{2}{*}{$\begin{array}{l}\text { Kejelasan } \\
\text { kalimat }\end{array}$} & $\begin{array}{l}\text { Kalimat yang } \\
\text { digunakan dalam } \\
\text { modul mudah } \\
\text { dipahami }\end{array}$ & 80 & 83 & Baik & $\begin{array}{l}\text { Sangat } \\
\text { Baik }\end{array}$ \\
\hline & $\begin{array}{l}\text { Bahasa yang } \\
\text { digunakan } \\
\text { komunikatif dan } \\
\text { tidak } \\
\text { membosankan }\end{array}$ & 80 & 80 & Baik & Baik \\
\hline $\begin{array}{l}\text { Kejelasan } \\
\text { istilah }\end{array}$ & $\begin{array}{l}\text { Istilah-istilah yang } \\
\text { digunakan dalam } \\
\text { modul ini disertai } \\
\text { dengan penjelasan } \\
\text { dan mudah } \\
\text { dimengerti }\end{array}$ & 76 & 77 & Baik & Baik \\
\hline $\begin{array}{l}\text { Kesesuaian } \\
\text { contoh dengan } \\
\text { materi }\end{array}$ & $\begin{array}{l}\text { Modul ini } \\
\text { menjelaskan materi } \\
\text { menggunakan } \\
\text { contoh soal yang } \\
\text { sesuai dan disertai } \\
\text { dengan } \\
\text { penyelesaiannya. }\end{array}$ & 81 & 82 & Baik & Baik \\
\hline \multicolumn{6}{|c|}{ Kebermanfaatan Modul } \\
\hline \multirow[t]{2}{*}{$\begin{array}{l}\text { Kemudahan } \\
\text { belajar }\end{array}$} & $\begin{array}{l}\text { Petunjuk } \\
\text { penggunaan } \\
\text { moodul jelas dan } \\
\text { bisa membantu } \\
\text { dalam } \\
\text { menggunakan } \\
\text { modul ini }\end{array}$ & 80 & 85 & Baik & $\begin{array}{l}\text { Sangat } \\
\text { Baik }\end{array}$ \\
\hline & $\begin{array}{l}\text { Langkah-langkah } \\
\text { pembelajaran } \\
\text { dalam modul dapat } \\
\text { membantu } \\
\text { memudahkan } \\
\text { dalam memahami }\end{array}$ & 90 & 79 & $\begin{array}{l}\text { Sangat } \\
\text { baik }\end{array}$ & Baik \\
\hline
\end{tabular}




\begin{tabular}{|c|c|c|c|c|c|}
\hline & materi & & & & \\
\hline $\begin{array}{l}\text { Ketertarikan } \\
\text { menggunakan } \\
\text { modul }\end{array}$ & $\begin{array}{l}\text { Modul ini menarik } \\
\text { untuk dipelajari }\end{array}$ & 87 & 87 & $\begin{array}{l}\text { Sangat } \\
\text { baik }\end{array}$ & $\begin{array}{l}\text { Sangat } \\
\text { Baik }\end{array}$ \\
\hline $\begin{array}{l}\text { Peningkatan } \\
\text { motivasi belajar }\end{array}$ & $\begin{array}{l}\text { Modul ini dapat } \\
\text { membantu } \\
\text { meningkatkan } \\
\text { motivasi belajar } \\
\text { fisika }\end{array}$ & 87 & 85 & $\begin{array}{l}\text { Sangat } \\
\text { baik }\end{array}$ & $\begin{array}{l}\text { Sangat } \\
\text { Baik }\end{array}$ \\
\hline
\end{tabular}

Menurut pendapat (Smart.K,L\& Capple. J.L, 2006) kemungkinan besar persepsi mahasiwa tentang media yang dibuat oleh peneliti akan lebih menguntungkan bagi mahasiswa. Dari tabel 4 diatas dapat dilihat bahwa hasil persepsi mahasiswa terhadap emodul materi struktur inti yakni 10 item dengan kategori baik dan 12 item dengan kategori sangat baik. Rata-rata hasil persepsi mahasiswa secara keseluruhan 83,5\% dengan kategori sangat baik. Sedangkan untuk hasil persepsi mahasiswa terhadap e-modul materi radioaktivitas yakni 6 item dengan kategori baik dan 18 item dengan kategori sangat baik. Rata-rata hasil persepsi mahasiswa secara keseluruhan $89 \%$ dengan kategori sangat baik. Hal ini mengindikasikan bahwa e-modul materi struktur inti dan e-modul materi radioaktivitas sudah baik dan layak digunakan sebagai bahan ajar pada proses perkuliahan fisika atom inti.

Selain itu, pembelajaran campuran memadukan beragam media untuk mengajarkan materi ajar kepada siswa semakin marak dalam dunia pendidikan khususnya universitas (Coates, James \& Baldwin, 2005). Pembelajaran campuran sering memadukan penggunaan alat alat web seperti email, rekaman perkuliahan, blog, media online,e-modul, dan lainlain. Oleh karena itu, pembuatan e-modul sangat penting dalam membelajarkan mahasiswa di kelas sebagai alat bantu untuk menerepakan pembelajaran campuran.

Berkaitan dengan intsrumen yang digunakan, agar instrument yang digunakan teruji kevalidan dan realibiltasnya nya maka perlu dilkaukan uji validitas dan uji realibiltas terhadap instrument yang digunakan. Indikator kualitas sebuah alat ukur atau instrumen penelitian yang digunakan adalah reliabilitasnya dan validitas tindakan yang dilakukan. (Carolyn,C.L \& Winterstein, A .G, 2008).

Hasil uji validitas dengan menggunakan software SPSS. 21 dengan 1 item tergolong rendah, 1 item tergolong cukup, 4 item tergolong tinggi dan 16 item tergolong sangat tinggi. Sedangkan e-modul materi radioaktivitas diperoleh hasil uji validitas dengan menggunakan software SPSS 21 dengan 1 item tergolong rendah, 2 item tergolong cukup tinggi, dan 19 item tergolong sangat tinggi. Hasil olah data uji validitas ini seperti yang terlihat pada tabel 3. Hasil ini menunjukkan bahwa semua pernyataan yang digunakan untuk mengukur validitas instrument sudah tergolong sangat baik sehingga layak digunakan.

Selain uji validitas instrumen juga dilakukan uji reabiltas instrumen. Untuk emodul materi struktur inti diperoleh hasil uji realibiltas dengan software SPSS 21 menghasilkan nilai alpha 0,977. Setelah dibandingkan dengan alpha pada tabel maka nilai alpha hitung lebih besar dari alpha tabel maka diperoleh criteria reabiltas instrument sangat tinggi. Sedangkan untuk e-modul materi radioaktivitas diperoleh hasil uji realibiltas dengan software SPSS 21 menghasilkan nilai alpha 0,943. Setelah dibandingkan dengan alpha pada tabel maka nilai alpha hitung lebih besar dari alpha tabel maka diperoleh criteria reabiltas instrument juga sangat tinggi.

\section{KESIMPULAN}

Berdasarkan hasil penelitian dan pembahasan maka dapat disimpulkan bahwa emodul fisika atom dan inti materi struktur inti dan radioaktivitas sudah divalidasi oleh ahli media dan ahli materi . Persepsi mahasiswa terhadap e-modul fisika atom dan inti yakni rata-rata sebesar $83,5 \%$ (materi struktur inti) dan $89 \%$ (materi radioaktivitas) dengan kategori sangat baik.

\section{UCAPAN TERIMA KASIH}

Ucapan terima kasih kami ucapkan kepada Dekan FKIP UNJA dan ketua LP2M UNJA yang telah mendanai penelitian ini. 


\section{DAFTAR PUSTAKA}

Arikunto, S. 2010. Prosedur Penelitian Suatu Pendekatan Praktik. Jakarta: Rineka Cipta.

Arsyad, A. 2014. Media Pembelajaran. Jakarta: Rajawali.

Asyhar, Rayandra. 2010. Kreatif Mengembang kan Media Pembelajaran. Jakarta: Gaung Persada.

Branch, Robert Maribe. 2009. Instructional Design- the ADDIE Approach: Amerika Department of Educational Psychology and Instructional Technology University of Georgia.

Carolyn,C.L \& Winterstein, A .G.2008.Validity and reliability of measurement instruments used in research. $A m J$ Health-Syst Pharm-Vol 65 Dec 1, 2008: 2276.

Coates, H., James, R. \& Baldwin, G. 2005. A critical examination of the effects of learning management systems on university teaching and learning. Tertiary Education and Management, 11(1), 19-36. http://dx.doi.org/10.1080/13583883.200 5.9967137.

Daryanto. 2013. Menyusun Modul. Yogyakarta: Gava Media.

Harijanto, Muhammad. 2007. Pengembangan Bahan Ajar Untuk Peningkatan Kualitas Pembelajaran Program Pendidikan Pembelajar Sekolah dasar. Jurnal Didaktika., Vol.2 No.1 Maret 2007: 225

Muhidin, dkk. 2009. Analisis Korelasi, Regresi dan Jalur dalam Penulisan. Bandung: Pustaka Setia.

Smart.K,L\& Capple.J.L. 2006. Students' Perceptions of Online Learning: A Comparative Study. Journal of Information Technology Education,Vol.5,2006:2015

Sugiyono. 2009. Metod.e Penelitian Kuantitatif, Kualitatif dan $R \& D$. Bandung: Alfabeta. 